\title{
Çocuk Gelişimi Lisans Öğrencilerinin Küresel Vatandaşlık Düzeyi ile Çocuk Haklarına İlişkin Tutumları Arasındaki ílişki
}

\author{
Erhan ALABAY* \\ Sevcan YAĞAN GÜDER ${ }^{* *}$
}

\begin{abstract}
Öz: Bu araştırmanın amacı, çocuk gelişimi lisans öğrencilerinin küresel vatandaşlık düzeylerinin ve çocuk haklarına ilişkin tutumları arasındaki ilişkinin olup olmadığını ve farklı değişkenlere göre farklılaşıp farklılaşmadığını tespit etmektir. Bu araştırmada nicel araştırma yöntemlerinden ilişkisel tarama modeli kullanılmıştır. Araştırmanın örneklemini, İstanbul ili Anadolu Yakasında bulunan üniversitelerdeki sağlık bilimleri fakültesi çocuk gelişimi lisans bölümlerinde öğrenim gören ve rastgele örnekleme modelinden yararlanarak seçilen 197 çocuk gelişimi lisans öğrencisi oluşturmaktadır. Çalışmanın verileri Demografik Bilgi Formu, Morais ve Ogden (2011) tarafından geliştirilen ve Şahin ve Çermik (2014) tarafından Türkçe 'ye uyarlanan Küresel Vatandaşlık Ölçeği ve Karaman Kepenekçi (2006) tarafından geliştirilen Çocuk Haklarına İlişkin Tutum Ölçeği kullanılarak toplanmıştır. Çalışma sonucunda, lisans öğrencilerinin küresel vatandaşlık ve çocuk haklarına ilişkin tutumlarının ortalamanın üzerinde olduğu, akademik not ortalamasının anlamlı bir farklılaşmaya yol açtığı ve çocuk gelişimi lisans öğrencilerinin küresel vatandaşlık toplam puanları arttıkça, çocuk haklarına ilişkin tutumlarının da arttığı belirlenmiştir.
\end{abstract}

Anahtar Sözcükler: Çocuk Gelişimi, Lisans Öğrencileri, Küresel Vatandaşlık, Çocuk Hakları, Tutum

\section{The Relationship Between Global Citizenship Level and Attitudes Towards Children's Rights of Child Development Undergraduate Students}

\begin{abstract}
The aim of this study is to determine the relationship between child development undergraduate students' global citizenship levels and their attitudes towards children's rights and whether they differ according to different independent variables. In this study, relational survey model, one of the quantitative research methods, was used. The sample of the study consisted of 197 child development undergraduate students who were selected by using the random sampling model. Demographic Information Form, The Global Citizenship Scale developed by Morais and Ogden (2011) and adapted to Turkish by Şahin and Çermik (2014) and Attitude Scale on Children's Rights developed by Karaman Kepenekci (2006) were used. As a result of the study, it was found that undergraduate students' global citizenship levels and attitudes towards children rights were above the average, and academic average scores of the undergraduate students showed a significant difference. Finally, it was determined that the students' attitudes towards children's rights increased as the total global citizenship scores increased.
\end{abstract}

Keywords: Child Development, Undergraduate Students, Global Citizenship, Children's Right, Attitudes 
Dünyadaki politik ve ekonomik gelişmeler küreselleşme kavramını ortaya çıkarmıştır. Bir ülkede yaşanan ekonomik ya da politik kriz artık o ülkenin değil dünyanın sorunu haline gelmektedir. Ülkelerde yaşanan sorunlarla birlikte yaşanan göç olayları, insan gücünün yer değiştirmesi, ülke sınırlarının her an değişmesi gibi faktörler küreselleşmeyi zorunlu kılmıştır. Kan (2009a)'a göre küreselleşme, artık sadece politik ya da ekonomik bir kavram olmayıp kültürel bir boyut da kazanmıştır ve bu anlamıyla yeni bir dünya düzeni ve ortak kültürün gelişmesine zemin hazırlamıştır. Bu gelişmeler, vatandaşlığın boyutlarını da zenginleştirmiştir. Önceden sadece ülkesine karşı sorumlulukların bilincinde olmak yeterliyken, küresel gelişmeler sonucunda artık kendini bütün insanlığa karşı sorumlu hisseden, evrensel bilince sahip vatandaşların yetiştirilmesi önem kazanmıştır. Dolayısı ile bu süreç "küresel vatandaş" kavramını da ortaya çıkarmıştır (Kan, 2009a; 2009b).

Oxfam (2006), küresel vatandaşı dünyanın çeşitliliği ve kendisinin dünya vatandaşı olarak bundaki rolünün farkında olan, çeşitliliğe değer veren ve saygı duyan, dünyanın işleyişi hakkında bir anlayışı olan, sosyal adalete sıkı sıkıya bağlı, yerelden küresele kadar ortak çalışmalara katılan, dünyayı daha adil ve sürdürülebilir bir yer haline getirmek için başkalarıyla birlikte çalışan, eylemlerinin sorumluluğunu üstlenen kişiler olarak tanımlamıştır. Özellikle küreselleşen dünyada üniversitelerin hedeflerinden birinin de küresel vatandaşları yetiştirmek olduğu söylenebilir. Yükseköğretim programlarının uluslararası hale getirilmesi hem Türkiye'de hem de dünyada küresel vatandaş yetiştirme hedefleri ile bağlantılıdır. Küresel vatandaş yetiştirme gerekliliği özellikle Türkiye'de Avrupa Birliği ile müzakere süreci doğrultusunda giderek önem kazanmıştır (Şahin, Şahin ve Göğebakan Yıldız, 2016). Kültürlere saygılı ve dünya sorunlarına duyarlı bireylerin yetiştirilmesi UNESCO'dan Birleşmiş Milletlere kadar birçok uluslararası kurum ve sivil toplum kuruluşlarının önem verdiği bir konudur. Bu nedenle küresel vatandaş yetiştirmeye ilişkin eğitim uygulamaları geliştirilmektedir. Bu eğitimlerin temel amacı, bireylerin yaşadıkları toplumun özelliklerini kavramaları, uluslararası düzeyde yaşanan dünya sorunlarına ilişkin bakış açıları geliştirmeleri, bu sorunlara ilişkin çözümler üretmeleri ve kamu yaşamına etkin katılım sağlamaları beklenmektedir (National Council for the Social Studies [NCSS], 2002; Akt: Şahin, Şahin ve Göğebakan Yıldız, 2016).

Avrupa Birliği (2006) tüm bireylerin kişisel gelişim, etkin vatandaşlık, istihdam ve sosyal kabulü için sekiz temel yeterlik alanı belirlemiştir. Bu yeterlikler; hem anadilinde hem de yabancı dillerde iletişim kurabilme, matematik, bilim ve teknolojideki temel yeterlilikler, dijital yeterlilik, öğrenmeyi öğrenme, sosyal ve yurttaşlık yeterlikleri, girişim ve girişimcilik duygusuna sahip olma, kültürel farkındalık ve ifade becerisi olarak sıralanmıştır. Özellikle etkin vatandaşlığa ilişkin temel yeterlikler sosyal ve yurttaşlık yeterlikleri olarak tanımlanmıştır.

Sosyal yeterlikler, kişisel ve sosyal iyilik hali ile bağlantılı olup bireylerin, kendileri ve aileleri de dahil olmak üzere en iyi fiziksel ve zihinsel sağlığı nasıl sağlayabilecekleri konusunda bir anlayışa sahip olmaları ve sağlıklı bir yaşam biçimine nasıl katkıda bulunabileceği konusunda bilgi sahibi olmaları anlamına gelir. Bireyler ve gruplar arasında toplumsal cinsiyet eşitliği ve ayrımcılık yapılmaması, toplum ve kültür ile ilgili temel kavramların farkında olmak da aynı derecede önemlidir. Bu yetkinliğin temel becerileri, farklı ortamlarda yapıcı bir şekilde iletişim kurma, hoşgörüyü gösterme, farklı bakış açılarını ifade etme ve anlama, güven yaratma becerisi ile müzakere etme ve empati kurma becerisini içerir. Yurttaşlık yeterlikleri ise, demokrasi, adalet, eşitlik, vatandaşlık ve sivil haklar kavramları üzerine kurulmuştur. Yurttaşlık yeterliliği becerileri, kamusal alanda başkalarıyla etkili bir şekilde etkileşim kurma, yerel ve daha geniş toplumu etkileyen sorunları çözme konusunda dayanışma ve ilgi gösterme becerisi ile ilgilidir (Balbağ, Gürdoğan Bayır ve Ersoy, 2017; Lawy ve Biesta, 2006).

Öte yandan küreselleşme insan hakları, demokrasi, girişimcilik ve rekabete açık olma gibi değerleri de beraberinde getirmektedir (Doğan, 2000; Akt: Kan, 2009b). Dolayısı ile küresel vatandaşın temel yeterliliklerin sorunlara duyarlı olma, sorunların çözümüne ilişkin etkin katılım sağlama, demokrasi ve insan hakları kavramları ile ilişkili olduğu söylenebilir. Bu bağlamda özellikle çocuk hakları, çocuk hak ihlallerine duyarlılık, çocuk haklarına ilişkin bilgi ve tutum düzeyi de küresel vatandaşın özellikleri arasında sayılabilir. Demokrasi ve insan haklarının gelişimine duyarlı vatandaşın aynı zamanda çocuk haklarına yönelik bilgi ve tutum düzeyinin eksik olması, çocuk hak ihlallerine kayıtsız kalması bu bağlamda düşünülemez. Uluslararası hukukta çocuk haklarını düzenleyen temel yasal metin 20 Kasım 1989 tarihli Çocuk Haklarına Dair Birleşmiş 
Milletler Sözleşmesi'dir. Türkiye ise bu sözleşmeyi 1990 yılında imzalamış ve 1995 yılında yürürlüğe koymuştur. Çocuk Hakları Sözleşmesinin 42. maddesinde "Taraf Devletler, Sözleşme ilke ve hükümlerinin uygun ve etkili araçlarla yetişkinler kadar çocuklar tarafından da yaygın biçimde öğrenilmesini sağlamayı taahhüt ederler." denilmektedir. Dolayısı ile sözleşme taraf devlet aracıllğı ile yetişkinlere çocuk haklarına ilişkin bilgi sahibi olma sorumluluğu yüklemektedir (UNICEF, 2004).

Göç ve İnsani Yardım Vakfı tarafından 2015 yılında internet medyasına yansıyan haberlerden derlediği ve çocuk hak ihlallerini konu alan çalışmada 1 Ocak- 31 Aralık 2015 tarihlerinde yaşanan hak ihlal sayısının 6418 olduğu tespit edilmiştir. Belirtilen tarihler arasında 3 bin 897 çocuğun, çocuğa özgü adalet sisteminden yararlanması gerekirken yararlanamadığı; 416 çocuğun çeşitli nedenlerden hak ihlaline maruz kaldığı belirtilmiştir. Yine 2015 yılında yabancı uyruklu çocukların da Türkiye'de hak ihlaline maruz kaldığı ve bu sayının 319 olduğu tespit edilmiştir. Özellikle üniversitelerin çocuk sağlığı, gelişimi ve eğitimi ile ilgili bölümlerinde öğrenim gören öğrencilerin küresel vatandaşlık bağlamında çocuk haklarına yönelik bilgi ve tutum düzeylerinin önemli ve birbiri ile ilişkili olduğu düşünülmektedir. Öyle ki hem günlük hayatta hem de meslek hayatında pek çok çocuk ve ailesi ile çalışan bir meslek grubu olan çocuk gelişimcilerin, çocuk haklarına ilişkin bilgi düzeyleri ve tutumlarının, yaşanabilecek hak ihlallerini belirlemede, ilgili mercilere başvurmada ve "çocuğun yüksek yararı" bağlamında gerekli tedbirleri almada çocuğa ve ailesine yol gösterici bir konumda olduğu söylenebilir (Göç ve İnsani Yardım Vakfı, 2015). Dinç (2015) tarafından okul öncesi dönem çocuğu olan ebeveynlerin çocuk hakları eğitimi konusundaki görüşlerini inceledikleri çalışma sonucunda, çalışmaya katılan 20 ebeveynin 17 'sinin çocuk hakları eğitimi konusunda sorun yaşadığını belirtmiştir. Kent Kükürtçü'nün (2011) yaptığı çalışmada da ebeveynlere çocuk hakları ile ilgili verilen bilgilendirmeler sonucunda, ebeveynlerin çocuk haklarına daha fazla dikkate aldığı ve bunun davranışlarına yansıttıkları saptanmıştır. Covell ve Howe (1999) ise çocuklarla deneysel bir çalışma yürütmüşlerdir. Çocuk hakları eğitimi alan çocukların, eğitimi almayan çocuklara göre başkalarının haklarına daha fazla saygı gösterdiği sonucuna ulaşılmıştır. Bu araştırmaların bulguları doğrultusunda çocuk gelişimi mezunu olan her bir bireyin, aileleri veya çocukları çocuk hakları konusunda bilinçlendirmenin ve yol göstermenin o kişilerde olumlu tutum ve davranış değişikliğine neden olduğu sonucuna ulaşılmıştır. Bu durum ise çocuk gelişimcilerinin rolünün özellikle çocuk hakları konusundaki önemini bir kat daha arttırmaktadır.

Bu bağlamda, bu araştırmanın temel amacı, çocuk gelişimi lisans programında öğrenimini sürdüren lisans öğrencilerinin küresel vatandaşlık düzeylerinin ve çocuk haklarına ilişkin tutumlarının farklı değişkenlere göre incelenmesi ve lisans öğrencilerinin küresel vatandaşlık düzeyi bağımsız değişkeninin, çocuk haklarına ilişkin tutum bağımlı değişkeninin bir yordayıcısının olup olmadığının belirlenmesidir. Bu ana amaç doğrultusunda aşağıdaki alt problem cümlelerine cevaplar aranmıştır.

a. Çocuk gelişimi lisans öğrencilerinin küresel vatandaşlık düzey ve çocuk haklarına ilişkin tutum puan ortalamaları nasıldır?

b. Çocuk gelişimi lisans öğrencilerinin yaş, sınıf ve Genel Akademik Not Ortalaması (GANO) bağımsız değişkeni ile küresel vatandaşlık düzey ve çocuk haklarına ilişkin tutum puanları arasında anlamlı bir farklılaşma var mıdır?

c. Çocuk gelişimi lisans öğrencilerinin küresel vatandaşlık düzeyleri, çocuk haklarına ilişkin tutum değişkeninin bir yordayıcısı mıdır?

\section{Yöntem}

Bu bölümde, araştırmanın modeline, çalışma grubuna, veri toplama araçlarına ve veri analizi sürecine yer verilmiştir.

\section{Araştırmanın Modeli}

$\mathrm{Bu}$ araştırmada nicel araştırma yöntemi kullanılmıştır. Nicel araştırma yöntemlerinden ise ilişkisel taramadan yararlanılmıştır. Tarama modeli, var olan bir durum veya olayı olduğu şekilde betimlemeyi amaçlayan araştırma yaklaşımıdır (Karasar, 2009). İlişkisel tarama modeli ise, iki ya da daha fazla değişken 
arasında birlikte gerçekleşen bir değişimin varlığını belirlemeyi amaçlayan tarama yaklaşımıdır. İlişkisel tarama modeli ile değişkenler arasındaki ilişkinin neden sonuç ilişkisinden ziyade, bir değişkendeki herhangi bir durumun bilinmesi halinde diğer değişkenin kestirilmesinin sağlanmasında kullanılır (Karasar, 2005). Çocuk gelişimi lisans öğrencilerinin küresel vatandaşlık düzeylerinin, çocuk haklarına ilişkin tutumlarına etkisinin incelenmesi amacıyla ilişkisel tarama modeli kullanılarak çözümlenmeye çalışılmıştır.

\section{Çalışma Grubu}

Araştırmanın evreni, İstanbul ili Anadolu Yakasında bulunan üniversitelerdeki sağlık bilimleri fakültesi çocuk gelişimi lisans bölümlerinde öğrenimini sürdüren üniversite öğrencileri olarak belirlenmiştir. Bu kapsamda araştırmanın örneklemini, rasgele örnekleme modelinden yararlanarak üniversitelerde öğrenimini sürdüren 197 çocuk gelişimi lisans bölümü öğrencisi oluşturmaktadır. Çalışma grubuna gönüllü olarak dahil olan çocuk gelişimi lisans öğrencilerinin demografik bilgileri Tablo I'de verilmiştir.

Tablo I

Katılımcilarn Demografik Bilgileri

\begin{tabular}{|c|c|c|c|}
\hline Demografik Bilgiler & & $\mathrm{n}$ & $\%$ \\
\hline \multirow{3}{*}{ Cinsiyet } & Kadın & 182 & 92,4 \\
\hline & Erkek & 15 & 7,6 \\
\hline & Toplam & 197 & 100 \\
\hline \multirow{4}{*}{ Yaş } & $18-20$ yaş & 25 & 12,7 \\
\hline & $21-23$ yaş & 103 & 52,3 \\
\hline & 24 yaş ve üstü & 69 & 35,0 \\
\hline & Toplam & 197 & 100 \\
\hline \multirow{5}{*}{ Sinif } & 1. Sinif & 52 & 26,4 \\
\hline & 2. Sinif & 57 & 28,9 \\
\hline & 3. Sinif & 33 & 16,8 \\
\hline & 4. Sinif & 55 & 27,9 \\
\hline & Toplam & 197 & 100 \\
\hline \multirow{4}{*}{ Genel Akademik Not Ortalaması } & $1.00-2.00$ aras 1 & 43 & 21,8 \\
\hline & 2.01-3.00 aras1 & 111 & 56,4 \\
\hline & 3.01 ve üstü & 43 & 21,8 \\
\hline & Toplam & 197 & 100 \\
\hline
\end{tabular}

Tablo I incelendiğinde, araştırmaya katılan çocuk gelişimcilerinin \%92,4'ünün kadın, \%7,6'sının erkek, \%12,7'sinin 18-20 yaş arasında, \%52,3'ünün 21-23 yaş arasında ve \%35'inin 24 yaş ve üzerinde olduğu sonucuna ulaşılmıştır. Çocuk gelişimi lisans öğrencilerinin \%26,4'ünün 1. sınıfta, \%28,9'unun 2. sınıfta, \%16,8'inin 3. sinıfta ve \%27,9'unun 4. sınıfta öğrenimlerine devam ettiği tespit edilmiştir. Genel akademik not ortalamalarına göre incelendiğinde ise, araştırmaya katılan lisans öğrencilerinin \%21,8'inin 1.002.00 arasında, \%56,4'ünün 2.01-3.00 arasında ve \%21,8'inin 3.01-4.00 arasında ortalamaya sahip oldukları belirlenmiştir.

\section{Veri Toplama Araçları}

Araştırmada "Demografik Bilgi Formu", "Küresel Vatandaşlık Ölçeği" ve "Çocuk Haklarına İlişkin Tutum Ölçeği" kullanılmıştır.

Demografik bilgi formu. Demografik Bilgi Formu araştırmacılar tarafından oluşturulmuş olup, çalışma grubuna dahil edilen çocuk gelişimi lisans öğrencilerinin cinsiyet, yaş, sınıf ve genel akademik not ortalama değişkenlerinin belirlenmesini amaçlayan soruları içermektedir.

Küresel vatandaşlık ölçeği. Küresel Vatandaşlık Ölçeği ilk olarak Morais ve Ogden (2011) tarafından geliştirilmiştir. Şahin ve Çermik (2014) tarafından geçerlik ve güvenirlik analizleri yapılarak Türkçe 'ye uyarlanmıştır. Ölçeğin amacı, en az lise mezunu bireylerin küresel vatandaşlık düzeylerini belirlemektir. Ölçek, 30 maddeden ve üç alt boyuttan oluşmaktadır. Ölçeğin alt boyutları "Sosyal Sorumluluk", "Küresel Yetkinlik" ve "Küresel Sivil Katılım"dır. Ölçek 5'li likert tipinde hazırlanmış olup "kesinlikle katılmıyorum", "katılmıyorum", “kısmen katılıyorum", "katılıyorum” ve "kesinlikle katılıyorum” seçenekleri bulunmaktadır. Ölçekte bulunan "Sosyal Sorumluluk" alt boyutundaki tüm maddeler ters puanlanmaktadır. Ölçeğin 
toplamına ilişkin Cronbach Alpha değerinin .91, sosyal sorumluluk alt boyutunda .65, küresel yetkinlik alt boyutunda .88 ve küresel sivil katılım alt boyutunda ise .95 olduğu belirlenmiştir.

Çocuk haklarına ilişkin tutum ölçeği. Üniversite öğrencilerinin çocuk haklarına ilişkin tutumların belirlemek amacıyla kullanılan Çocuk Haklarına İlişkin Tutum Ölçeği Karaman Kepenekçi (2006) tarafından geliştirilmiştir. Ölçek 5'li likert tipinde hazırlanmış olup "tamamen katılıyorum", "katılıyorum", "kararsızım", "katılıyorum" ve "tamamen katılmıyorum" ifadeleri bulunmaktadır. Çocuk Haklarına İlişkin Tutum Ölçeği, çocukların yaşamsal, gelişimsel, korunma ve katılım haklarını içerek toplam 22 maddeden oluşmaktadır. Ölçekte 19'u olumlu, 3'ü olumsuz ifade bulunmaktadır. Bu nedenle olumsuz ifadeler ters puanlanmaktadır. Ölçekten alınacak olan en düşük puan 22, en yüksek puan ise 110'dur. Karaman Kepenekçi (2006) tarafından ölçeğin geçerlik ve güvenirlik çalışması yapılmış olup, ölçeğin tek faktörlü olduğu belirlenmiştir. Ölçekteki maddelerin madde korelasyon katsayılarının .32 ile .61 arasında değiştiği saptanmıştır. Güvenirlik çalışması doğrultusunda da Cronbach Alpha iç tutarlılık katsayısının .85, yarı test güvenirlik katsayısının ise .77 olarak belirlenmiştir. Yapılan bu araştırmada ise güvenirlik cronbach alpha değerinin .95 olarak bulunmuştur.

\section{Veri Toplama ve Analizi Süreci}

Araştırmada kullanılan ölçeği uyarlayan ve geliştiren araştırmalardan ölçek kullanımı ile ilgili gerekli izinler alındıktan sonra İstanbul Anadolu Yakasında yer alan ve sağlık bilimleri fakültesi kapsamında çocuk gelişimi bölümü olan üniversitelerin listesi hazırlanmış olup, rastgele olarak belirlenen üniversitelerden gerekli izinler alınmıştır. Araştırmaya katılan çocuk gelişimi lisans öğrencilerinin de araştırmaya katılımı için gönüllülük esas alınmıştır. Her bir öğrenciye ölçeklerden önce onam formu verilmiş ve çalışmaya katılmak istediklerine dair onam formu imzalatılmıştır. Toplanan veriler SPSS 21.0 programına girilmiştir. Verilerin homojen olup olmadığı, normal dağılım gösterip göstermediği ve çarpıklık ve basıklık katsayıları incelenmiştir. Ortaya çıkan sonuçlar doğrultusunda verilerin analizinde parametrik testler kullanılmıştır. Verilerin analizinde Tek Yönlü Varyans Analizi (ANOVA), korelasyon ve çoklu regresyon analizlerinden yararlanılmıştır.

\section{Bulgular}

Araştırmaya katılan çocuk gelişimi lisans öğrencilerinin küresel vatandaşlık düzeylerine ve çocuk haklarına ilişkin tutumlarına dair tanımlayıcı istatistik sonuçlar Tablo II'de verilmiştir.

\section{Tablo II}

Katılımcıların Küresel Vatandaşlık Ölçeği Alt Boyut ve Toplam Puanların ve Çocuk Haklarına İlişkin Tutum Ölçeği Puanının Tanımlayıcı İstatistikleri

\begin{tabular}{lccc}
\hline Küresel Vatandaşlık Ölçeği & $\mathrm{n}$ & $\bar{x}$ & $\mathrm{ss}$ \\
\hline Sosyal Sorumluluk & 197 & 3,393 & 1,025 \\
Küresel Yetkinlik & 197 & 3,237 &, 966 \\
Küresel Sivil Katılım & 197 & 3,286 & 1,011 \\
Ölçek Toplam Puan & 197 & 3,290 & 1,098 \\
\hline Çocuk Hakların İlişkin Tutum Ölçeği & $\mathrm{n}$ & $\bar{x}$ & $\mathrm{ss}$ \\
\hline Ölçek Toplam Puan & 197 & 4,185 & 1,344 \\
\hline
\end{tabular}

Tablo II incelendiğinde, araştırmaya dahil olan lisans öğrencilerinin küresel vatandaşlık düzeylerini belirlemek amacıyla uygulanan Küresel Vatandaşlık Ölçeği toplam puan ve sosyal sorumluluk, küresel yetkinlik ve küresel sivil katılım alt boyutlarında "kısmen katılıyorum" ile "katılıyorum" arasında bir düzeye sahip olduğu sonucuna ulaşılmıştır. Aynı tabloda görülmektedir ki katılımcıların çocuk haklarına ilişkin tutum puanlarının "katılıyorum" ile "tamamen katılıyorum" arasında bir düzeye sahip oldukları tespit edilmiştir. Bir diğer ifade ile çocuk gelişimi lisans öğrencilerinin çocuk haklarına ilişkin tutumlarının yüksek düzeyde, küresel vatandaşlık düzeylerinin ise orta düzeyde olduğu sonucuna ulaşılmıştır.

Araştırmaya katılan lisans öğrencilerinin yaş ve sınıf bağımsız değişkeni ile küresel vatandaşlık düzeyleri arasında anlamlı bir farklılaşmanın olup olmadığını belirlemek amacıyla Tek Yönlü Varyans Analizi (ANOVA) uygulanmıştır. Yaş bağımsız değişkeni ile ilgili analiz sonuçları Tablo III'te, sınıf bağımsız değişkeni ile ilgili analiz sonuçları ise Tablo IV'te verilmiştir. 
Erhan ALABAY \& Sevcan YAĞAN GÜDER

Tablo III

Katılımcıların Yaş Değişkeni ile Küresel Vatandaşlık Ölçeği Puanları Arasında Yapılan Tek Yönlü Varyans Analizi Sonuçları

\begin{tabular}{|c|c|c|c|c|c|c|c|c|}
\hline Küresel Vatandaşlık & Yaş & $\mathrm{n}$ & $\bar{x}$ & ss & SD & $\mathrm{F}$ & $\mathrm{p}$ & Anlamlı Fark \\
\hline \multirow{3}{*}{ Sosyal Sorumluluk } & 18-20 yaş & 25 & 21,440 & 4,042 & \multirow{3}{*}{$2 / 194$} & \multirow{3}{*}{1,148} & \multirow{3}{*}{,319 } & \multirow{3}{*}{---- } \\
\hline & $21-23$ yaş & 103 & 20,359 & 4,137 & & & & \\
\hline & 24 yaş ve üstü & 69 & 19,971 & 4,214 & & & & \\
\hline \multirow{3}{*}{ Küresel Yetkinlik } & $18-20$ yaş & 25 & 36,360 & 6,217 & \multirow{3}{*}{$2 / 194$} & \multirow{3}{*}{,226 } & \multirow{3}{*}{,798 } & \multirow{3}{*}{---- } \\
\hline & $21-23$ yaş & 103 & 35,728 & 8,166 & & & & \\
\hline & 24 yaş ve üstü & 69 & 35,159 & 8,534 & & & & \\
\hline \multirow{3}{*}{ Küresel Sivil Katılım } & $18-20$ yaş & 25 & 42,800 & 11,120 & \multirow{3}{*}{$2 / 194$} & \multirow{3}{*}{, 010} & \multirow{3}{*}{,990 } & \multirow{3}{*}{---} \\
\hline & $21-23$ yaş & 103 & 42,611 & 13,142 & & & & \\
\hline & 24 yaş ve üstü & 69 & 42,884 & 11,628 & & & & \\
\hline \multirow{3}{*}{ Toplam Puan } & $18-20$ yaş & 25 & 100,600 & 14,341 & \multirow{3}{*}{$2 / 194$} & \multirow{3}{*}{ 183 } & \multirow{3}{*}{833} & \multirow{3}{*}{---} \\
\hline & $21-23$ yaş & 103 & 98,699 & 19,287 & & & & \\
\hline & 24 yaş ve üstü & 69 & 98,014 & 18,002 & & & & \\
\hline
\end{tabular}

Tablo IV

Katılımcıların Öğrenim Gördü̆̆̈̈ Sınıf Değişkeni ile Küresel Vatandaşlık Ölçeği Puanları Arasında Yapılan Tek Yönlü Varyans Analizi Sonuçları

\begin{tabular}{|c|c|c|c|c|c|c|c|c|}
\hline Küresel Vatandaşlık & Sinif & $\mathrm{n}$ & $\bar{x}$ & ss & SD & $\mathrm{F}$ & $\mathrm{p}$ & Anlamlı Fark \\
\hline \multirow{4}{*}{ Sosyal Sorumluluk } & 1. Sinif & 52 & 21,019 & 4,060 & \multirow{4}{*}{$3 / 193$} & \multirow{4}{*}{ 698 } & \multirow{4}{*}{, 554} & \multirow{4}{*}{---} \\
\hline & 2. Sinif & 57 & 20,193 & 4,364 & & & & \\
\hline & 3. Sinif & 33 & 20,393 & 4,344 & & & & \\
\hline & 4. Sinif & 55 & 19,890 & 3,937 & & & & \\
\hline \multirow{4}{*}{ Küresel Yetkinlik } & 1. Sinif & 52 & 35,076 & 7,232 & \multirow{4}{*}{ 3/193 } & \multirow{4}{*}{,996 } & \multirow{4}{*}{,396 } & \multirow{4}{*}{---- } \\
\hline & 2. Sinif & 57 & 36,157 & 9,090 & & & & \\
\hline & 3. Sinif & 33 & 33,818 & 8,427 & & & & \\
\hline & 4. Sinif & 55 & 36,618 & 7,392 & & & & \\
\hline \multirow{4}{*}{ Küresel Sivil Katılım } & 1. Sinif & 52 & 42,038 & 11,614 & \multirow{4}{*}{$3 / 193$} & \multirow{4}{*}{2,331} & \multirow{4}{*}{,076 } & \multirow{4}{*}{---- } \\
\hline & 2. Sinif & 57 & 43,561 & 13,743 & & & & \\
\hline & 3. Sinif & 33 & 38,303 & 12,261 & & & & \\
\hline & 4. Sinif & 55 & 45,181 & 10,949 & & & & \\
\hline \multirow{4}{*}{ Toplam Puan } & 1. Sinif & 52 & 98,134 & 16,538 & \multirow{4}{*}{$3 / 193$} & \multirow{4}{*}{1,888} & \multirow{4}{*}{ 133 } & \multirow{4}{*}{---- } \\
\hline & 2. Sinif & 57 & 99,912 & 20,782 & & & & \\
\hline & 3. Sinif & 33 & 92,515 & 17,967 & & & & \\
\hline & 4. Sinif & 55 & 101,690 & 16,510 & & & & \\
\hline
\end{tabular}

Tablo III ve Tablo IV incelendiğinde, çocuk gelişimi lisans öğrencilerinin yaş ve sınıf bağımsız değişkeni ile küresel vatandaşlık düzeyleri arasında anlamlı bir farklılaşmaya rastlanmamıştır. Bir diğer ifadeyle, lisans öğrencilerinin yaşları ve öğrenim gördükleri sınıf düzeyleri vatandaşlık düzeylerini etkilememektedir.

Çocuk gelişimi lisans öğrencilerinin genel akademik not ortalaması (GANO) bağımsız değişkeni ile küresel vatandaşlık düzeyleri arasında anlamlı bir farklılaşmanın olup olmadığını belirlemek amacıyla Tek Yönlü Varyans analizi (ANOVA) uygulanmıştır. Tek yönlü varyans analizi sonuçları Tablo V'te verilmiştir.

Tablo V

Katılımcıların Genel Akademik Not Ortalaması (GANO) Değişkeni ile Küresel Vatandaşlık Ölçeği Puanları Arasında Yapılan Tek Yönlü Varyans Analizi Sonuçları

\begin{tabular}{|c|c|c|c|c|c|c|c|c|}
\hline Küresel Vatandaşlık & GANO & $\mathrm{n}$ & $\bar{x}$ & ss & SD & $\mathrm{F}$ & $\mathrm{p}$ & Anlamlı Fark \\
\hline \multirow{3}{*}{ Sosyal Sorumluluk } & $1.00-2.00$ aras 1 & 43 & 19,232 & 4,460 & \multirow{3}{*}{$2 / 194$} & \multirow{3}{*}{4,513} & \multirow{3}{*}{, $012^{*}$} & \multirow{3}{*}{$1-3$} \\
\hline & 2.01-3.00 aras1 & 111 & 20,225 & 3,981 & & & & \\
\hline & 3.01 ve üstü & 43 & 21,837 & 3,951 & & & & \\
\hline \multirow{3}{*}{ Küresel Yetkinlik } & $1.00-2.00$ aras1 & 43 & 35,069 & 8,710 & \multirow{3}{*}{$2 / 194$} & \multirow{3}{*}{,125 } & \multirow{3}{*}{,883 } & \multirow{3}{*}{---- } \\
\hline & 2.01-3.00 aras1 & 111 & 35,729 & 8,331 & & & & \\
\hline & 3.01 ve üstü & 43 & 35,837 & 6,679 & & & & \\
\hline \multirow{3}{*}{ Küresel Sivil Katılım } & $1.00-2.00$ aras 1 & 43 & 41,162 & 12,565 & \multirow{3}{*}{$2 / 194$} & \multirow{3}{*}{,556 } & \multirow{3}{*}{, 574} & \multirow{3}{*}{---- } \\
\hline & 2.01-3.00 aras1 & 111 & 42,873 & 12,559 & & & & \\
\hline & 3.01 ve üstü & 43 & 43,930 & 11,578 & & & & \\
\hline \multirow{3}{*}{ Toplam Puan } & $1.00-2.00$ aras 1 & 43 & 95,465 & 18,959 & \multirow{3}{*}{$2 / 194$} & \multirow{3}{*}{1,230} & \multirow{3}{*}{,294 } & \multirow{3}{*}{----} \\
\hline & $2.01-3.00$ aras1 & 111 & 98,828 & 18,746 & & & & \\
\hline & 3.01 ve üstü & 43 & 101,604 & 15,790 & & & & \\
\hline
\end{tabular}

${ }^{*} \mathrm{p}<.05$ 
Tablo V'e göre, çocuk gelişimi lisans öğrencilerinin genel akademik not ortalaması (GANO) bağımsız değişkeni ile Küresel Vatandaşlık Ölçeği toplam puanı, küresel yetkinlik ve küresel sivil katılım alt boyutlarında anlamlı bir farklılaşmaya rastlanmazken, küresel vatandaşlık ölçeği sosyal sorumluluk alt boyutunda anlamlı bir farklılaşmaya rastlanmıştır. Sosyal sorumluluk alt boyutunda anlamlı farklılaşma genel akademik not ortalaması 1.00-2.00 arasındakiler ile 3.01 ve üstü öğrenciler arasında olduğu saptanmıştır. Farklılaşmanın 3.01 ve üstü genel akademik not ortalamasına sahip öğrencilerin lehine olduğu belirlenmiştir. Bir diğer ifade ile genel akademik not ortalaması yüksek olan öğrencilerin, düşük olan öğrencilere göre sosyal sorumluluk düzeylerinin daha fazla olduğu sonucuna ulaşılmıştır.

Araştırmaya katılan lisans öğrencilerinin yaş ve sınıf bağımsız değişkeni ile çocuk haklarına ilişkin tutumları arasında anlamlı bir farklılaşmanın olup olmadığının saptanması amacıyla Tek Yönlü Varyans Analizi (ANOVA) uygulanmıştır. Yaş bağımsız değişkeni ile ilgili analiz sonuçları Tablo VI'da, sınıf bağımsız değişkeni ile ilgili analiz sonuçları ise Tablo VII'de sunulmuştur.

Tablo VI

Katılımcıların Yaş Değişkeni ile Çocuk Haklarına İlişkin Tutum Ölçeği Puanları Arasında Yapılan Tek Yönlü Varyans Analizi Sonuçları

\begin{tabular}{|c|c|c|c|c|c|c|c|c|}
\hline $\begin{array}{l}\text { Çocuk Haklarına İlişkin } \\
\text { Tutum Ölçeği }\end{array}$ & Yaş & $\mathrm{n}$ & $\bar{x}$ & Ss & SD & $\mathrm{F}$ & $\mathrm{p}$ & $\begin{array}{c}\text { Anlamli } \\
\text { Fark }\end{array}$ \\
\hline \multirow{3}{*}{ Toplam Puan } & $18-20$ yaş & 25 & 96,240 & 15,354 & \multirow{3}{*}{$2 / 194$} & \multirow{3}{*}{820} & \multirow{3}{*}{,442 } & \multirow{3}{*}{---- } \\
\hline & $21-23$ yaş & 103 & 91,310 & 17,023 & & & & \\
\hline & 24 yaş ve üstü & 69 & 91,710 & 18,903 & & & & \\
\hline
\end{tabular}

\section{Tablo VII}

Katılımcıların Ö̆̆renim Gördü̆̆̈̈ Sınıf Değişkeni ile Çocuk Haklarına İlişkin Tutum Ölçeği Puanları Arasında Yapılan Tek Yönlü Varyans Analizi Sonuçları

\begin{tabular}{|c|c|c|c|c|c|c|c|c|}
\hline $\begin{array}{l}\text { Çocuk Haklarına İlişkin } \\
\text { Tutum Ölçeği }\end{array}$ & Sinif & $\mathrm{n}$ & $\bar{x}$ & s.s. & SD & $\mathrm{F}$ & $\mathrm{p}$ & $\begin{array}{l}\text { Anlaml } \\
\text { Fark }\end{array}$ \\
\hline \multirow{4}{*}{ Toplam Puan } & 1. Sinif & 52 & 92,576 & 17,286 & \multirow{4}{*}{ 3/193 } & \multirow{4}{*}{,152 } & \multirow{4}{*}{,928 } & \multirow{4}{*}{---- } \\
\hline & 2. Sinif & 57 & 91,947 & 17,240 & & & & \\
\hline & 3. Sinif & 33 & 90,333 & 12,456 & & & & \\
\hline & 4. Sinif & 55 & 92,781 & 20,651 & & & & \\
\hline
\end{tabular}

Tablo VI ve Tablo VII incelendiğinde, araştırmaya katılan çocuk gelişimi lisans öğrencilerinin yaş ve sınıf bağımsız değişkeni ile Çocuk Haklarına İlişkin Tutum Ölçeği puanları arasında anlamlı bir farklılaşmanın olmadığı saptanmıştır. Bir diğer deyişle, bu çalışma kapsamında çocuk gelişimi lisans öğrencilerinin yaş ve sınıf düzeyi değişkeni, çocuk haklarına ilişkin tutumlarını etkilememektedir.

Lisans öğrencilerinin genel akademik not ortalamaları (GANO) ile Çocuk Haklarına İlişkin Tutum Ölçeği puanları arasında anlamlı bir farklılaşmanın olup olmadığını belirlemek amacıyla Tek Yönlü Varyans Analizi (ANOVA) uygulanmıştır. Tek yönlü varyans analizi sonuçları Tablo VIII'de verilmiştir.

\section{Tablo VIII}

Katılımcıların Genel Akademik Not Ortalaması (GANO) Değı̧şkeni ile Çocuk Haklarına İlişkin Tutum Ölçeği Puanları Arasında Yapılan Tek Yönlü Varyans Analizi Sonuçları

\begin{tabular}{|c|c|c|c|c|c|c|c|c|}
\hline $\begin{array}{l}\text { Çocuk Haklarına İlişkin } \\
\text { Tutum Ölçeği }\end{array}$ & GANO & $\mathrm{n}$ & $\bar{x}$ & ss & SD & $\mathrm{F}$ & $\mathrm{p}$ & $\begin{array}{l}\text { Anlamlı } \\
\text { Fark }\end{array}$ \\
\hline \multirow{3}{*}{ Toplam Puan } & $1.00-2.00$ aras 1 & 43 & 84,930 & 19,367 & \multirow{3}{*}{$2 / 194$} & \multirow{3}{*}{4,769} & \multirow{3}{*}{, $010^{*}$} & \\
\hline & 2.01-3.00 aras1 & 111 & 94,171 & 15,730 & & & & $1-2$ \\
\hline & 3.01 ve üstü & 43 & 93,814 & 18,410 & & & & $1-3$ \\
\hline
\end{tabular}

Tablo VIII incelendiğinde, lisans öğrencilerinin genel akademik not ortalamaları ile çocuk haklarına ilişkin tutumları arasında anlamlı bir farklılaşmaya rastlandığı tespit edilmiştir. Bu farklılaşmanın genel akademik not ortalamaları 1.00-2.00 olan ile 2.01-3.00, 3.01 ve üstü olan öğrenciler arasında olduğu sonucuna varılmıştır. Farklılaşma not ortalaması yüksek olan öğrencilerin lehinedir. 
Çocuk gelişimi bölümü lisans öğrencilerinin küresel vatandaşlık düzeyleri ile çocuk haklarına ilişkin tutumlarının karşılaştırılmasında, değişkenlerin arasındaki ilişkileri saptayabilmek amacıyla korelasyon analizi yapılmıştır. Korelasyon analizi Tablo IX'da verilmiştir.

Tablo IX

Araştırmanın Ana Değ̆işkenleri Arasındaki Basit Korelasyon Katsayıları, Ortalama Ve Standart Sapma Değerleri

\begin{tabular}{|c|c|c|c|c|c|}
\hline Değişkenler & 1 & 2 & 3 & 4 & 5 \\
\hline Sosyal Sorumluluk (1) & 1 & & & & \\
\hline Küresel Yetkinlik (2) &, $345^{* *}$ & 1 & & & \\
\hline Küresel Sivil Katılım (3) &, $189^{* *}$ &, $706^{* *}$ & 1 & & \\
\hline Küresel Vatandaşlık Toplam (4) & 052 &, $841^{* *}$ & $946^{* *}$ & 1 & \\
\hline Çocuk Haklarına İlişkin Tutum Toplam (5) & 017 &, $346^{* *}$ & $320^{* *}$ & $374^{* *}$ & 1 \\
\hline Ortalama & 20,360 & 35,609 & 42,731 & 98,700 & 92,076 \\
\hline SS & 4,156 & 8,053 & 12,327 & 18,216 & 17,499 \\
\hline
\end{tabular}

$\mathrm{n}: 197,{ }^{*} \mathrm{p}<.05,{ }^{* *} \mathrm{p}<.01$

Tablo IX incelendiğinde, çocuk haklarına ilişkin tutum puanları ile küresel yetkinlik, küresel sivil katılım ve küresel vatandaşlık ölçeği toplam puan arasında pozitif yönlü orta düzeyde bir ilişki olduğu tespit edilmiştir. Korelasyon analizinden çıkan sonuç doğrultusunda küresel yetkinlik, küresel sivil katılım ve küresel vatandaşlık ölçeği toplam puanlarının çocuk haklarına ilişkin tutumunu ne derece yordadığını belirlemek amacı ile çoklu regresyon analizi uygulanmıştır. Çoklu regresyon analizi Tablo X'da verilmiştir.

Tablo X

Çocuk Haklarına İlişkin Tutum İçin Çoklu Regresyon Sonuçları

\begin{tabular}{lccccc}
\hline & B & S. Hata & $B$ & $t$ & $p$ \\
\hline Küresel Yetkinlik &, 223 &, 037 &, 298 & 1,255 &, 211 \\
\hline Küresel Sivil Katılım &, 039 &, 310 &, 018 &, 126 &, 900 \\
\hline Küresel Vatandaşlik Toplam Puan &, 315 &, 199 &, 440 & & 2,059 \\
\hline $\mathrm{R}^{2}$ & .15 & & & & \\
\hline
\end{tabular}

Regresyon analizinden elde edilen sonuçlar doğrultusunda küresel yetkinlik, küresel sivil katılım ve küresel vatandaşlık toplam puanlarının doğrusal kombinasyonunun çocuk haklarına ilişkin tutumu anlamlı bir düzeyde yordadığı tespit edilmiştir. Çocuk haklarına ilişkin tutumlarını yordamada, küresel vatandaşlık toplam puanının $\left(B=.440, \mathrm{t}_{(197)}=2.059 \mathrm{p}<.05\right)$ en güçlü yordayıcısı olarak ortaya çıkmıştır. Bu bulgu doğrultusunda çocuk gelişimi lisans öğrencilerinin küresel vatandaşlık toplam puanları arttıkça, çocuk haklarına ilişkin tutumlarının da arttı̆̆ını göstermektedir.

\section{Sonuç ve Tartışma}

Çocuk gelişimi lisans programında öğrenimini sürdüren lisans öğrencilerinin küresel vatandaşlık düzeylerinin ve çocuk haklarına ilişkin tutumlarının farklı değişkenlere göre incelenmesi ve lisans öğrencilerinin küresel vatandaşlık düzeyi bağımsız değişkeninin, çocuk haklarına ilişkin tutum bağımlı değişkeninin bir yordayıcısı olup olmadığının belirlenmesi amacıyla yapılan bu çalışmada, ilk bulgu küresel vatandaşlık düzeyinin "kısmen katılıyorum" ile "katılıyorum" arasında bir düzeye sahip ve çocuk haklarına ilişkin tutumlarının ise "katılıyorum" ile "tamamen katılıyorum" arasında bir düzeye sahip olduğu tespit edilmiştir. Bunun sebebinin çocuk gelişimi lisans programındaki aldıkları derslerden kaynaklı olduğu düşünülebilir. Özellikle lisans programı içerisinde çocuklar ile ilgili hem teorik hem de uygulamalı derslerin bulunduğu görülmektedir. Bu dersler sayesinde lisans öğrencilerinin çocuk haklarına ve küresel vatandaşlık düzeylerine dair farkındalıklarının artmasına sebep olduğu düşünülebilir. Karaman Kepenekçi (2006)'nin eğitim fakültesi kapsamındaki lisans programlarındaki öğretmen adaylarının çocuk haklarına ilişkin tutumlarının saptanması üzerine yaptığı çalışmasında da lisans öğrencilerinin ölçeğin maddelerine yüksek oranda olumlu seçenekleri seçtikleri tespit edilmiştir. Sınıf öğretmenliği anabilim dalı öğrencilerinin tutumlarının diğer bölümlere oranla daha yüksek çıktığı saptanmıştır. Bu bulgu sonucunda öğrencilerin sınıf öğretmenliği lisans programı süresince aldıkları çocuk hakları ya da insan haklarına ilişkin derslerin diğer anabilim dallarının lisans programına oranla daha fazla yer verildiği sonucuna ulaşılmıştır. Değirmenci (2011) tarafından öğretmen adaylarının çocuk haklarına ilişkin tutumlarının incelenmesi amacıyla yapılan çalışmada 
da benzer sonuçlara ulaşılmıştır. Özellikle uygulamalı derslerde çocuklarla iç içe olan ve çocuk haklarına ilişkin lisans dersi alan öğretmen adaylarının çocuk haklarına ilişkin tutumlarının daha yüksek olduğu tespit edilmiştir. Ancak diğer taraftan, Kaya (2011) öğretmen adaylarının çocuk haklarına ilişkin görüşlerini incelediği çalışmasında çalışmaya katılan lisans öğrencilerinden \%14,6'sı Çocuk Hakları Sözleşmesini okuduklarını, \%85,4'ü ise okumadıklarını belirtmişlerdir. Oysa birebir çocuklarla çalışan öğretmenlerin bu konuya ilişkin daha duyarlı olmaları hem meslek etiği gereği hem de vatandaşlık görevi olarak düşünülebilir.

Çocuk gelişimi lisans öğrencilerinin küresel vatandaşlık düzeylerinin orta değerin üzerinde olduğu bulgusu yine lisans programında görmüş oldukları farklı kültürlerde çocuk ve aile, değerler eğitimi, farklılıklara saygı ve sosyoloji gibi derslerle ile ilgili olabilir. Göl (2013)'ün sosyal bilgiler öğretmen adaylarının küresel vatandaşlık tutum düzeylerinin farklı değişkenler açısından incelenmesini amaçladığı çalışmada da, lisans programında ilgili derslerin olmasından kaynaklı sosyal bilgiler öğretmen adaylarının küresel vatandaşl1k düzeylerinin yüksek olduğu görülmüştür. Kaya ve Kaya (2012) Türkçe, Fen, Bilgisayar, Matematik ve Sosyal Bilgiler Öğretmenliği lisans programında okuyan öğrencilerin küresel vatandaşlık algıları ile ilgili yaptıkları çalışmada, "İnternet Okuryazarlığı Bilgisi" alt boyutu dışında "Küreselleşmenin Olumlu Etkileri", "Uluslararası Konuların Farkında Olma”, "Uluslararası Gündemi Takip Etme" alt boyutlarında Sosyal Bilgiler Öğretmenliği lisans öğrencileri lehine anlamlı sonuçlar elde etmişlerdir. Dolayısı ile bu veriler, bize öğrenim görülen lisans programı ve bu programın derslerinin içeriğinin küresel vatandaş yetiştirmede önemli olabileceğini göstermektedir. Ancak yine de istenilen düzeyde olup olmadığı önemli bir sorun olarak karşımıza çıkmaktadır. Örneğin, okul öncesi öğretmenlerinin dünya vatandaşlığı kavramı ve okul öncesi dönemde dünya vatandaşlığı eğitimi ile ilgili görüşlerinin incelendiği bir araştırmada, öğretmenlerin çoğu okul öncesi eğitim programının dünya vatandaşlığını içermesi gerektiğini belirtirken mezun oldukları öğretmen eğitim programının ve alan deneyimlerinin çocuklara dünya vatandaşlı̆̆ını öğretmeye hazırlamadığını düşündükleri ortaya çıkmıştır (Ceylan, 2013). Lisans programları ile ilgili benzer bir bulgu da Gürdoğan Bayır, Göz ve Bozkurt (2014) tarafından yapılan ve sınıf öğretmenliği öğretmen adaylarının Sosyal Bilgiler Dersinde küresel vatandaşlık eğitimine ilişkin görüşlerini ortaya koymayı amaçlayan çalışmanın bulgularıdır. Öğretmen adaylarının Sosyal Bilgiler dersinin küresel vatandaşlık eğitimine katkısına ilişkin verdikleri yanıtlarda bazıları küresel vatandaşlık eğitiminde Sosyal Bilgiler dersini yeterli olarak görürken bazıları ise yetersiz olarak gördükleri belirlenmiştir. Günümüzün küreselleşen dünyasında yalnızca belirli lisans programlarında değil, okul öncesinden başlayarak tüm eğitim kademelerinde küresel vatandaşlar yetiştirmek oldukça önemli ve güncel bir konudur.

Ayrıca lisans öğrencilerinin lisans süresince daha fazla sosyal aktivitelere katıldığı düşünüldüğünde, lisans öğrencilerinin küresel vatandaşlık düzeylerinin ve çocuk haklarına ilişkin tutumlarının yüksek olmasının sebeplerinden birisinin de katıldıkları sosyal aktivitelerden kaynaklı olduğu düşünülebilir. Osmanağaoğlu (2007) tarafından lise son sınıf öğrencilerinin çocuk haklarına ilişkin görüşlerinin saptanması amacıyla yapılan çalışma sonucunda da, sosyal aktivitelere daha fazla katılım gösteren öğrencilerin çocuk haklarına ilişkin daha olumlu görüşe sahip olduğu sonucuna ulaşılmıştır. Kantek ve Yıldırım (2016)'ın lisans eğitiminde öğrencilerin sosyal aktivitelere katılımının eleştirel düşünme eğilimlerine etkisini araştırdığı meta analiz çalışmasında da, sosyal aktivitelere katılan öğrencilerin eleştirel düşünme eğilimlerinin yüksek olduğu görülmüştür.

Araştırma kapsamında erkek ve kadın çocuk gelişimi lisans öğrenci sayısı dengesiz bir yapıda olması ve sadece 15 erkek çocuk gelişimi öğrencisi olduğundan dolayı cinsiyet bağımsız değişkeni ile çocuk haklarına ilişkin tutum ve küresel vatandaşlık düzeylerine bakılamamıştır. Fakat cinsiyet alanında yapılan çalışmalar incelendiğinde kadın üniversite öğrencilerinin erkeklere oranla yüksek düzeyde çocuk haklarına ilişkin tutum ve küresel vatandaşlık düzeylerine sahip olduğuna rastlanmaktadır. Karaman Kepenekçi (2006)'nin üniversite öğrencilerinin çocuk haklarına ilişkin görüşleri üzerinde yaptığı araştırmada, kadın öğrencilerin erkek öğrencilere göre çocuk haklarına ilişkin daha olumlu bir görüşe sahip oldukları tespit edilmiştir. Ancak, Kaya (2011) çalışmasında erkek katılımcıların kadın katılımcılara göre çocuk haklarına karşı daha olumlu bir görüşe sahip olduklarını göstermektedir. Peker (2012) tarafından yapılan çalışmada da sınıf öğretmenlerinin çocuk haklarına ilişkin tutumlarının cinsiyet, medeni durum, yaş grupları, görev yaptığı yer, mezun olduğu 
kurum, eğitim düzeyi, kıdem grupları ve okuttuğu sınıf değişkenlerine göre farklılık göstermediği sonucuna ulaşılmıştır. Dolayısı ile çocuk haklarına ilişkin tutumda cinsiyet faktöründen çok, öğrenim görülen lisans programında çocuk haklarına ilişkin bir dersin olup olmamasının sorgulanması daha önemli görülmektedir. Çünkü profesyonel bir meslek olan öğretmenliğin cinsiyet faktöründen çok mesleğe yönelik ilgi, tutum ve donanım ile ilgili olabileceği düşünülmektedir. Ferreira (2011) da çalışmasında küresel konulara yönelik tutumda kadın öğrencilerin lehine anlamlı bir farklılık olduğu sonucuna ulaşmıştır. Bunun sebeplerinden birisinin kadınların erkeklere göre empatik ve sosyal duyarlılı̆̆ının fazla olması düşünülebilir. Başbay, Kağnıcı ve Sarsar (2013) kadın öğretim elemanlarının kültürel farkındalık ve beceri düzeylerinin, erkek öğretim elemanlarına göre daha yüksek olduğunu tespit etmişlerdir. Engin ve Genç (2015), sınıf öğretmeni adaylarının çok kültürlü eğitime ilişkin tutumlarını belirledikleri çalışmalarının sonucunda, sınıf öğretmeni adaylarının çok kültürlü eğitime yönelik tutumlarının kadın öğretmen adayları lehine anlamlı farklılaşma gösterdiği belirlenmiştir. Akbulut ve Sağlam (2010) tarafından sınıf öğretmenlerinin empatik eğilimlerini inceledikleri araştırmasında da kadın sınıf öğretmenlerinin, erkek sınıf öğretmenlerine göre empatik eğilimlerinin anlamlı derecede yüksek olduğu sonucuna ulaşılmıştır. Dorak ve Vurgun (2006), Korkmaz (2001), Rehber (2007) ve Seymen (2007)'nin araştırma sonuçlarında da kadınların erkeklere göre empatik eğilimlerinin daha yüksek olduğu belirlenmiştir. Külekçi ve Özgan (2015) tarafından üniversite öğrencilerinin algılarına göre sosyal sorumluluk alanında görev alma nedenleri ve sonuçlarının belirlenmesi amacıyla yapılan çalışmada da üniversite öğrencilerinin empati becerilerinin kazanımında sosyal sorumluluk faaliyetlerinin etkili olduğu sonucuna ulaşılmıştır. Aynı çalışmada sosyal sorumluluk faaliyetlerine katılma nedenlerinden birisi ise toplumsal sebeplerdir. Özellikle üniversite öğrencilerinin, toplumda değişimi oluşturmak, ülkedeki sorunlara çözüm bulmak, bilinçli bir toplum oluşturmak ve farkındalığı sağlamak, toplumda daha yararlı olmak ve vatandaşlık görevi gibi temel küresel vatandaşlık düzeylerini etkileyebilecek sebepler doğrultusunda sosyal sorumluluk faaliyetlerine katılmaktadır. Kadın lisans öğrencilerinin erkek lisans öğrencilerine göre küresel vatandaşlık düzeylerinin anlamlı derecede yüksek olmasının nedenlerinden birisi de kadınların erkeklere oranla sosyalleşme düzeylerinin fazla olması olabilir. Elma ve diğerleri (2010)'nin yaptıkları çalışma sonucunda da, cinsiyet değişkenine göre sosyalleşme boyutunda anlamlı bir ilişkiye rastlanmıştır. Kadın öğretmen adaylarının sosyalleşme boyutuna ilişkin algılarının, erkek öğretmen adaylarına göre daha olumlu olduğu tespit edilmiştir. Öte yandan Karaca ve Çoban (2015)'ın yaptıkları araştırma sonucunda ise, sosyal bilgiler öğretmen adaylarının küresel vatandaşlık tutum düzeylerinde cinsiyet, sınıf farkı, coğrafi bölge, siyasal olayları takip düzeyi, sivil toplum kuruluşlarına katılım durumu, anne ve baba eğitim durumu değişkenlerine göre anlamlı bir farklılaşma olmadığı görülmüştür. Yine, Kaya ve Kaya (2012) tarafından üniversite öğrencileri ile yapılan çalışma sonuçlarına göre, erkek öğrenciler kadın öğrencilere göre küreselleşmenin olumlu etkileri olduğunu daha fazla düşünürken, erkek öğrencilerin başkalarına yardım etme konusunda daha duyarlı oldukları tespit edilmiştir. Uluslararası gündemi takip etme konusunda ise kadın öğrencilerin erkek öğrencilere göre gündemi daha fazla takip ettikleri bulunmuştur. Ancak, alan yazın genel olarak incelendiğinde çalışmaların büyük çoğunluğunda cinsiyet faktörünün kadınların lehine anlamlı bir farklılaşmaya yol açtığı söylenebilir. Burada tartışılması gereken olgu belki de cinsiyet faktöründen öte, toplumsal cinsiyet kalıp yargıları olarak adlandırdığımız cinsiyetlere yüklediğimiz anlamlar ve bu anlamlar doğrultusunda bireylerin yetiştirilme süreci olabilir.

Çocuk gelişimi lisans öğrencilerinin genel akademik not ortalamalarına göre çocuk haklarına ilişkin tutum puanlarında ve küresel vatandaşlık ölçeği alt boyutu sosyal sorumluluk puanlarında anlamlı farklılaşmaya rastlanmıştır. Akademik not ortalaması yükseldikçe çocuk haklarına tutum puanlarının ve sosyal sorumluluk puanlarının arttığı tespit edilmiştir. Özellikle genel not ortalaması yüksek olan öğrencilerin mesleklerine karşı daha ilgili, öğrenmeye karşı daha istekli, özgüvenli ve güdülenme düzeylerinin yüksek olduğu düşünülebilir. Yaşar Ekici (2014) tarafından öğretmen adaylarının çocuk haklarına yönelik tutumlarının bazı değişkenler açısından incelenmesi amacıyla gerçekleştirdiği çalı̧̧ma sonucuna göre, lisans öğrencilerinin mesleğe ilgi duyması ve bu ilgi doğrultusunda mesleği tercih etme durumunun öğrencilerin çocuk haklarına ilişkin tutumlarını etkilediği saptanmıştır. Mesleğini bilinçli olarak seçenlerin topluma ve çocuğa karşı daha duyarlı oldukları sonucuna ulaşılmıştır. Türkmen, Sarıkaya ve Saygılı (2013)'nın öğrencilerin çevresel duyarlılığı üzerine yapmış oldukları çalışma sonucunda da, genel akademik not 
ortalaması yüksek olan çocukların çevresel duyarlılığının daha fazla olduğu tespit edilmiştir.

Araştırmanın son bulgusu ise çocuk gelişimi lisans öğrencilerinin küresel vatandaşlık toplam puanları arttıkça, çocuk haklarına ilişkin tutumlarının da artmasıdır. Bir başka deyişle, Küresel Vatandaşlık Ölçeğinin alt boyutları olan küresel yetkinlik, küresel sivil katılım ve küresel vatandaşlık toplam puanlarının doğrusal kombinasyonunun çocuk haklarına ilişkin tutumu anlamlı bir düzeyde yordadığı tespit edilmiştir. Alan yazında, küresel vatandaşlık ve çocuk hakları ilişkisini ortaya koyan bir çalışma olmamakla birlikte araştırmacılar açısından bu beklenen bir sonuç olarak yorumlanabilir. Avrupa Birliği (2006)'nin etkin vatandaşlığa ilişkin belirlediği temel yeterliklerden yurttaşlık yeterlikleri arasında demokrasi, adalet, eşitlik, vatandaşlık ve sivil haklar kavramları yer almaktadır. Ayrıca, Doğan (2000) küreselleşmenin insan hakları, demokrasi, girişimcilik ve rekabete açık olma gibi değerleri de beraberinde getirdiğini belirtmiştir (Akt: Kan, 2009b). Dolayısı ile küresel vatandaşlık ile çocuk hakları arasında doğrudan bir ilişki bulunduğunu söylemek yanlış olmaz. Çünkü çocuk hakları evrensel bir değerdir ve insan hakları arasında yerini almıştır (Doğan ve Durualp, 2011; Karaman Kepenekçi, 1999). İnsan hakları ile küresel vatandaşlık arasında ise sıkı bir ilişki vardır.

Küreselleşen dünyanın insan gücünü karşılayacak nesilleri yetiştirmede, özellikle küresel vatandaşlar yetiştirmek oldukça önemlidir. Bu nedenle özellikle tüm eğitim aşamalarını kapsayacak, gelişimsel özelliklere uygun küresel vatandaşlık eğitimi verilmesi gerekmektedir. Küresel vatandaşlık ile bağlantılı olarak özellikle çocuklarla çalışacak meslek profesyonellerine lisans eğitimleri sürecinde çocuk hakları derslerinin verilmesi büyük bir gereklilik olarak karşımıza çıkmaktadır. Aynı zamanda çocuk gelişimi bölümünde uygulama ve topluma hizmet derslerinde özellikle çocuk haklarına dair bilincin arttırılması için çalışmalara yer verilip, bu konularla ilgili projeler gerçekleştirilebilir. Özellikle lisans programları incelendiğinde, çocuk hakları dersinin çoğunlukla çocuk gelişimi bölümlerinde seçmeli ders olarak yer aldığ 1 tespit edilmiştir. Bu dersin, seçmeli ders kategorisinden çıkartılarak zorunlu ders kapsamına alınması ve bu dersin içeriğinin daha çok uygulamaya veya proje çalışmalarına yönelik işlenmesi önerilebilir.

\section{Kaynaklar}

Akbulut, E. ve Sağlam, H. İ. (2010). Sınıf öğretmenlerinin empatik eğilim düzeylerinin incelenmesi. Uluslararası Insan Bilimleri Dergisi, 7(2), 1068-1083.

Avrupa Birliği (2006). Recommendation of the European Parliament and of the Council on key competencies for lifeliong learning. Official Journal of the European Union, http://eur-lex.europa.eu/legalcontent/EN/TXT/PDF/?uri=CELEX:32006H0962\&from=EN adresinden erişildi.

Başbay, A., Kağnıcı, Y. ve Sarsar, F. (2013). Eğitim fakültelerinde görev yapmakta olan öğretim elemanlarının çok kültürlü yeterlik algılarının incelenmesi. Turkish Studies - International Periodical For The Languages, Literature and History of Turkish or Turkic, 8(3), 47-60.

Balbağ, N. L., Gürdoğan Bayır, Ö. ve Ersoy, A. F. (2017). İnsan hakları, yurttaşlık ve demokrasi dersini öğretmenler ve öğrenciler nasıl algılıyor? Sakarya University Journal of Education, 7(1), 223-241.

Ceylan, Ş. (2013). Okul öncesi öğretmenlerinin dünya vatandaşlı̆̆ı eğitimi ile ilgili görüşleri. Kuramsal Ĕ̆itimbilim Dergisi, 7(1), 78-93.

Covell, K. ve Howe, R. B. (1999). The impact of children's rights education: A Canadian study. International Journal of Children's Rights, 7(2), 171-183.

Değirmenci, T, (2011). Öğretmen adaylarının çocuk haklarına ilişkin tutumlarının incelenmesi. XX. Ĕ̆gitim Bilimleri Kurultayı, Mehmet Akif Ersoy Üniversitesi, Burdur.

Dinç, B. (2015). Okul öncesi eğitim kurumuna devam eden çocukların ebeveynlerinin çocuk hakları eğitimi konusundaki görüşleri. Eğitimde Nitel Araştırmalar Dergisi, 3(1), 7-25.

Doğan, İ. ve Durualp, E. (2011). Sosyal bilgiler dersi alan dördüncü ve beşinci sınıf öğrencilerinin çocuk haklarına dair görüşlerinin karşılaştırılması. 1. Türkiye Çocuk Hakları Kongresi Bildiri Kitabı, Cilt (1), 293- 
301.

Dorak, F. ve Vurgun, N. (2006). Takım sporları açısından empati ve takım birlikteliği ilişkisi. Spormetre Beden Eğitimi ve Spor Bilimleri Dergisi, 4(2), 73-77.

Elma, C., Kesten, A., Kıroğlu, K., Uzun, E. M., Dicle, A. N. ve Palavan, Ö. (2010). Öğretmen adaylarının topluma hizmet uygulamaları dersine ilişkin algıları. Kuram ve Uygulamada Eğitim Yönetimi, 16(2), 231-252.

Engin, G. ve Genç, S. Z. (2015). Sınıf öğretmeni adaylarının çok kültürlü eğitime yönelik tutumları (Çanakkale 18 Mart Üniversitesi Örneği). Route Educational and Social Science Journal, 2(2), 30-39.

Ferreira, R. (2011). Development of an instrument to measure high school students' global awareness and attitudes: looking through the lens of social sciences (Yayımlanmamış doktora tezi). Florida International University. http://digitalcommons.fiu.edu/cgi/viewcontent.cgi?article=1479\&context=etd adresinden erişildi.

Göç ve İnsani Yardım Vakfı (2015). 2015 internet medyası çocuk hak ihlali izleme raporu. www.giyav.org/tr/s/2015_internet_Medyası_Çocuk_Hak_ìhlali_İzleme_Raporu adresinden erişildi.

Göl, E (2013). Sosyal bilgiler öğretmen adaylarının küresel vatandaşlık tutum düzeylerinin farklı değişkenler açısından incelenmesi. (Yayınlanmamış yüksek lisans tezi). Ahi Evran Üniversitesi, Kırşehir.

Gürdoğan Bayır, Ö., Göz, N. L. ve Bozkurt, M.(2014). Sınıf öğretmeni adaylarına göre sosyal bilgiler dersinde küresel vatandaşlık. Eğitim Bilimleri Araştırmaları Dergisi, 4(2), 145-162.

Kan, Ç. (2009a). Sosyal bilgiler eğitiminde küresel vatandaşlık. Pamukkale Üniversitesi Eğitim Fakültesi Dergisi, $26,25-30$.

Kan, Ç. (2009b). Değişen değerler ve küresel vatandaşlık eğitimi. Kastamonu Ĕ̆itim Dergisi, 17(3), 895-904.

Kantek, F. ve Yıldırım, N. (2016). Sosyal etkinliklere katılımın öğrenci hemşirelerin eleştirel düşünme eğilimlerine etkisi: Meta analiz çalışması. Eğitim ve Öğretim Araştırmaları Dergisi, 5(4), 58-64.

Karaca, S. ve Çoban, A. (2015). Sosyal bilgiler öğretmen adaylarının küresel vatandaşlık tutum düzeylerinin farklı değişkenler açısından incelenmesi. Akademik Sosyal Araştırmalar Dergisi, 3(17), 10-22.

Karaman Kepenekçi, Y. (2006) A study of university students' attitudes towards children's rights in Turkey. The International Journal of Children's Rights, 14(3), 307-319.

Karaman Kepenekçi, Y. (1999). İlköğretimde insan hakları. Ankara Üniversitesi Eğitim Fakültesi Dergisi, 32(1), 227-236.

Karasar, N. (2005) Bilimsel araştırma yöntemi. Ankara: Nobel Yayın Dağıtım.

Karasar, N. (2009). Bilimsel araştırma yöntemleri. Ankara: Nobel Yayın Dağıtım.

Kaya, B. ve Kaya, A. (2012). Teknoloji çağında öğretmen adaylarının küresel vatandaşlık algıları. Sakarya University Journal of Education, 2(3), 81-95.

Kaya, S.B. (2011). Öğretmen adaylarının çocuk haklarına ilişkin görüşleri (Yayınlanmamış yüksek lisans tezi). Afyon Kocatepe Üniversitesi, Afyon.

Kent Kükürtçü, S. (2011). 5-6 yas çocuklarının ailelerin ve öğretmenlerinin kullandıkları disiplin yöntemlerinin çocuk hakları ile ilişkisinin incelenmesi (Yayımlanmamış yüksek lisans tezi). Hacettepe Üniversitesi, Ankara.

Korkmaz, N. (2001, Ekim). Uludağ üniversitesi beden eğitimi ve spor bölümü öğrencilerinin empatik becerilerinin cinsiyete göre karşılaştırılması. II.Uluslararası Spor Psikolojisi Sempozyumu, İzmir, Türkiye.

Külekçi, E. ve Özgan, H. (2015). Üniversite öğrencilerinin algılarına göre sosyal sorumluluk alanında görev alma nedenleri ve sonuçları. Anadolu Ĕ̆itim Liderliği ve Öğretim Dergisi, 3(2), 1-15.

Lawy, R. S. ve Biesta, G. J. J. (2006). Citizenship-as-practice: The educational implications of an inclusive and relational understanding of citizenship. British Journal of Educational Studies, 54(1), 34-50. 
Osmanağaoğlu, Y. (2007). Uşak ili lise son sınıf öğrencilerinin çocuk haklarına ilişkin görüşleri (Yayımlanmamış yüksek lisans tezi). Ankara Üniversitesi, Ankara.

Oxfam. (2006). Education for global citizenship: A guide for schools. http://www.oxfam.org.uk/education/globalcitizenship/global-citizenship-guides adresinden erişildi.

Peker, R. (2012). Sinıföğretmenlerinin demokratik tutumları ile çocuk haklarına yönelik tutumlarının değerlendirilmesi (Yayınlanmamış yüksek lisans tezi). Mehmet Akif Ersoy Üniversitesi, Burdur.

Rehber, E. (2007). Illköğretim ikinci kademe öğrencilerinin empatik eğilim düzeylerine göre çatışma çözme davranışlarının incelenmesi. (Yayınlanmamış yüksek lisans tezi). Çukurova Üniversitesi, Adana.

Seymen, S. (2007). KKTC Gazimă̆usa devlet hastanesinde çalışan yüksek hemşire ve hemşirelerin empatik ĕ̆gilimleri ile yatan hastaların hemşirelere karşı duydukları memnuniyet düzeyleri (Yayınlanmamış yüksek lisans tezi). KKTC Yakın Doğu Üniversitesi, Kuzey Kıbrıs.

Şahin, M., Şahin, S. ve Göğebakan Yıldız, D. (2016). Sosyal bilgiler eğitimi programı ve dünya vatandaşlığı: Öğretmen adaylarının perspektifinden. Hacettepe Üniversitesi Eğitim Fakültesi Dergisi, 31(2), 369-390.

Türkmen, M., Sarıkaya, N. ve Saygılı, M. (2013). Öğrencilerin çevresel duyarlılık düzeylerinin satın alma davranışına etkisi üzerine bir araştırma: Sakarya Üniversitesi örneği. Sosyal ve Beşeri Bilimler Dergisi, 5(2), 238-249.

UNICEF (2004). Çocuk haklarına dair sözleşme. https://www.unicef.org/turkey/\%C3\%A7ocukhaklar\%C4\%B1na-dair-s\%C3\%B6zle\%C5\%9Fme adresinden erişildi.

Yaşar Ekici, F. (2014). Öğretmen adaylarının çocuk haklarına yönelik tutumlarının bazı değişkenlere göre incelenmesi. Akademik Sosyal Araştırmalar Dergisi, 2(8), 66-77. 


\section{EXTENDED ABSTRACT}

\section{Introduction}

The concept of globalization has emerged due to political and economic developments in the world. The economic or political crisis in a country is no longer the problem of the country but the world. Factors such as migrations, displacement of manpower and change of the country's boundaries necessitates globalization. According to Kan (2009a), globalization is not only a political or economic concept, but it has also gained a cultural dimension, and in this sense, it has paved the way for the development of a new world order and common culture. These developments have enriched the dimensions of citizenship. While it is enough to be aware of the responsibilities towards the country in the past, today, because of global developments, it has become important to bring up citizens who feel a responsibility towards humanity and have global consciousness. Therefore, this process has given rise to the emergence of the concept of "global citizen". Oxfam (2006) defines global citizen as a person, who is aware of the diversity of the world and his role as world citizens, such as; valuing and respecting diversity, having an idea about the workings of the world, showing strict obedience to social justice, attending to the joint studies range from local to global, and working together with others to make the world just and sustainable place, and lastly, feeling responsible for his/her actions. On the other hand, globalization brings values such as human rights, democracy, entrepreneurship and openness to competition (Doğan, 2000; Cited by: Kan, 2009b). Therefore, it can be said that the basic competencies of global citizens are related to being sensitive to problems, active participation in solving problems, democracy and human rights. In this context, children's rights, sensitivity to child rights violations, level of knowledge and attitude on children's rights are among the features of the global citizen. Hence, it is inconceivable that the citizen, who is sensitive to the development of democracy and human rights, to possess insufficient knowledge and attitude on children's rights, and shows indifference to child rights violations. One of the objectives of universities in the globalized world is to raise global citizens.

\section{Method}

In this context, the main purpose of this study is to investigate the global citizenship levels of the undergraduate students in child development department and their attitudes towards children's rights according to different variables and to determine whether the independent variable of the global citizenship level of undergraduate students is a predictor of attitude-dependent variable of child rights. In this study, the relational screening model was used. The study group consists of 197 child development undergraduate students who are volunteers from the Child Development Undergraduate Program students of the Faculty of Health Sciences of various universities in the Anatolian side of Istanbul. Demographic Information Form was created by researchers as a data collection tool, Global Citizenship Scale developed by Morais and Ogden (2011) and adapted to Turkish by Şahin and Çermik (2014) and Attitude Scale on Children's Rights developed by Karaman Kepenekci (2006) were used.

\section{Results}

As a result of the study, it was concluded that the attitudes of child development department's undergraduate students towards children's rights were found to be at a high level and their global citizenship levels were moderate. The findings of this study also indicated that age and class of undergraduate students do not affect their citizenship levels and attitudes towards children's rights. A significant difference was found in the attitude scores of the child development undergraduate students according to their general academic grade point averages and social responsibility scores of the global citizenship scale sub-dimension. As the academic grade point average increases, attitude scores and social responsibility scores of children's rights also increased in parallel. It was found that there was a positive relationship between the attitudes towards children rights and global competence, global civic engagement and global citizenship scale. Based on the results obtained from the regression analysis, it was found that the linear combination of global competence, global civic engagement and global citizenship scores significantly predicted the attitudes towards children's rights. ) In predicting their attitudes towards children's rights, the global total score of citizenship was found to be the strongest predictor $\left(B=.440, t_{(197)}=2.059 \mathrm{p}<.05\right)$. In line with this finding, it can be seen that as the 
global citizenship total scores of children development undergraduate students increase, their attitudes towards children's rights also increase in parallel.

\section{Conclusion}

It is of utmost importance to raise global citizens that meet the manpower of the globalizing world. For this reason, global citizenship education should be given in accordance with developmental characteristics, particularly covering all stages of education. In connection with global citizenship, it is now a great necessity to give children's rights courses in the process of undergraduate education, especially for those who will professionally work with children. 